\title{
REVERSAL BY GONADOTROPHINS OF THE LUTEOLYTIC EFFECT OF OESTROGEN IN THE CYCLIC GUINEA-PIG
}

\author{
J. B. CHOUDARY AND G. S. GREENWALD \\ Departments of Obstetrics and Gynecology and Anatomy, \\ University of Kansas Medical Center, Kansas City, U.S.A. \\ (Received 22nd Fuly 1968, accepted 9th September 1968)
}

\begin{abstract}
Summary. To determine the mechanism by which oestrogen induces luteolysis, cyclic guinea-pigs were given a single subcutaneous injection of $10 \mu \mathrm{g}$ of oestradiol cyclopentylpropionate (OECP) on Day $\mathrm{l}$ and daily subcutaneous injections of various gonadotrophins on Days 1 to 9 . The mean diameter of the corpora lutea and their histology were used as end points in assessing luteal status.

Ovine LH, prolactin, or a combination of both did not reverse the effect of OECP. Daily treatment with $200 \mu \mathrm{g}$ of ovine FSH in normal saline partially counteracted the luteolytic effect of OECP on the size and morphology of the corpora lutea. A combination of $100 \mu \mathrm{g}$ of FSH and $1 \mathrm{mg}$ of prolactin or $10 \mu \mathrm{g}$ of $\mathrm{LH}$ was less effective than $200 \mu \mathrm{g}$ of FSH. Treatment with 10 or 25 i.u. of PMSG in saline or $200 \mu \mathrm{g}$ of FSH in $5 \%$ beeswax-sesame oil suspension counteracted the luteolytic effect of OECP in the majority of animals. The corpora lutea regressed when the initial injection of PMSG was deferred until Day 4.

The results indicate that oestrogen induces luteal regression in the cyclic guinea-pig by inhibiting the pituitary secretion of FsH which is apparently necessary - at least in part-for the normal maintenance of corpora lutea.
\end{abstract}

\section{INTRODUCTION}

Exogenous oestrogen exerts a luteolytic effect on the corpora lutea of the cyclic guinea-pig (Choudary \& Greenwald, 1968a). Evidence from this study and from an earlier investigation by Spies, Gier \& Wheat (1964), showed that the luteal regression was not the result of a direct effect of oestrogen on the ovary. Deanesly (1963) suggested that oestrogen may induce luteal regression in pregnant guinea-pigs by affecting the secretion of pituitary gonadotrophins. Oestrogen induces luteolysis in the pregnant hamster by inhibiting the secretion of pituitary FSH (Greenwald, 1965), which is a component of the luteotrophic complex of this species (Greenwald, 1967), and destroys the corpus luteum in the cow, an effect which is reversed by the simultaneous injection of human chorionic gonadotrophin (Wiltbank, 1966). 
The present investigation was designed to determine how oestrogen exerts its luteolytic effect on the corpora lutea of the cyclic guinea-pig, which may help to clarify the factors responsible for the normal maintenance of the corpus luteum in this species.

\section{MATERIALS AND METHODS}

A total of eighty-three virgin guinea-pigs of smooth, American coloured and white strains, weighing 400 to $700 \mathrm{~g}$, was used in this study. The animals were checked daily for vaginal opening and daily vaginal smears were then examined. Day 1 of the oestrous cycle designates the morning after ovulation which is characterized by leucocytic infiltration of the vaginal smear following full cornification on the previous day.

Treatments were started in all groups on Day 1 of the cycle. Control animals received a single subcutaneous injection of $0.2 \mathrm{ml}$ cottonseed oil on Day 1 . The hormonal preparations administered to the remaining animals were oestradiol cyclopentylpropionate (OECP), oestrone, ovine FSH (NIH-s4), bovine LH (NIH-B5), ovine prolactin (NIH-s8), and PMSG (Equinex-Ayerst Laboratories). Each hormone was injected subcutaneously as a single daily dose in $0.2 \mathrm{ml}$ of solvent. Cottonseed oil was the solvent for OECP and peanut oil for oestrone. Normal saline was the diluent for all the gonadotrophic hormones with the exception of FSH, for which $5 \%$ beeswax-sesame oil suspension was used.

The corpora Iutea of most of the animals were marked by Indian ink on Day 4 of the cycle to establish their identity. At autopsy on Day 10, the ovaries of each animal were examined for follicles and corpora lutea under a dissecting microscope. In appropriate cases, ovulation was verified by the recovery of tubal ova and confirmed by histological study of the ovaries. After weighing in pairs, one or two ovaries of each animal were fixed in Bouin's solution, sectioned serially at $10 \mu$ and stained with Mallory Azan. With the aid of an ocular micrometer, luteal size was estimated by averaging two diameters at right angles to each other in the largest section of each corpus luteum.

An attempt was made in preliminary experiments to use the decidual cell response as a physiological end point in determining whether the corpora lutea were functional. One uterine horn of each of seven cyclic animals was traumatized between Days 4 and 7 by placing loops of threads through the uterine wall, scraping the endometrial surface or transecting the uterine wall on the antimesometrial side. At autopsy on Day 10, none of the animals showed macroscopic swellings characteristic of deciduomata. In view of these negative results, the morphology and the mean diameter of the corpus luteum were used as end points in assessing luteal status.

The morphological features of the different ovarian components, the mean diameter of the corpora lutea and the ovarian weights for different groups were compared with those of the control and OECP-treated groups. The data on ovarian weights and the mean diameter of the corpus luteum were tested for statistical significance by Student's $t$-test (Snedecor, 1965). Other details on experimental designs are described at appropriate places in the text. 


\section{RESULTS}

To confirm the results of a previous study (Choudary \& Greenwald, 1968a), cyclic animals were injected with cottonseed oil or $10 \mu \mathrm{g}$ OECP on Day 1 (Table 1, Groups 1 and 2). At autopsy on Day 10, the corpora lutea of control animals were large and slightly vascular. Large follicles were also visible on the surface of the ovary (mean ovarian weight \pm S.E. $131 \cdot 3 \mathrm{mg} \pm 22 \cdot 2$ ). Histological examination revealed large, normal Graafian follicles and normal corpora lutea characterized by luteal cells arranged in columns. Mitotic figures were also present. By contrast, OECP caused a significant $(P<0.0005)$ reduction in the size of the corpora lutea which were seen to be in an

TABLE 1

EFFECT OF GOMBINING OESTRADIOL GYCLOPENTYLPROPIONATE WITH GONADOTROPHIN ON THE CORPORA LUTEA OF GYCLIC GUINEA-PIGS

\begin{tabular}{|c|c|c|c|}
\hline Group No. & Treatment & $\begin{array}{c}\text { Mean diameter of } C L \\
(m m \pm S . E .) \\
\text { on Day } 10\end{array}$ & $\underset{\text { animals* }}{\text { Normal } C L / \mathcal{N} \text { of }}$ \\
\hline $\begin{array}{r}1 \\
2 \\
3 \\
4 \\
5 \\
6 \\
7 \\
8 \\
9 \\
10\end{array}$ & $\begin{array}{l}\text { Control } \\
10 \mu \mathrm{g} \text { OECP } \ddagger \\
10 \mu \mathrm{g} \text { oestrone } \\
10 \mu \mathrm{g} \text { OECP }+1 \mathrm{mg} \text { prolactin } \$ \\
10 \mu \mathrm{g} \text { OECP }+10 \mu \mathrm{g} \mathrm{LH} \\
10 \mu \mathrm{g} \text { OECP }+50 \mu \mathrm{g} \mathrm{LI} \\
10 \mu \mathrm{g} \text { OECP }+50 \mu \mathrm{g} \mathrm{FSH} \\
10 \mu \mathrm{g} \text { OECP }+200 \mu \mathrm{g} \mathrm{FSH} \\
50 \mu \mathrm{g} \mathrm{LH} \\
50 \mu \mathrm{g} \mathrm{LH}+1 \mathrm{mg} \text { prolactin }\end{array}$ & $\begin{array}{lc}1.44 \pm 0.06 & (17) \dagger \\
0.74 \pm 0.09 & (15) \\
1.33 \pm 0.47 & (9) \\
0.71 \pm 0.13 & (12) \\
0.82 \pm 0.03 & (15) \\
0.57 \pm 0.08 & (13) \\
0.80 \pm 0.07 & (14) \\
1.04 \pm 0.04 & (18) \\
1.43 \pm 0.17 & (9) \\
1.46 \pm 0.09 & (11)\end{array}$ & $\begin{array}{l}5 / 5 \\
0 / 4 \\
2 / 3 \\
0 / 4 \\
0 / 4 \\
0 / 4 \\
0 / 4 \\
0 / 4 \\
3 / 3 \\
3 / 3\end{array}$ \\
\hline
\end{tabular}

* No. of animals having normal cL on Day 10.

$\dagger$ Number in parentheses refers to number of CL measured.

¥ Oestrogens were administered on Day 1.

$\$$ Gonadotrophins were administered daily on Days 1 to 9 .

advanced stage of regression, characterized by cytoplasmic vacuolization in luteal cells, a pycnotic appearance of the nuclei, absence of mitotic figures, and loss of discrete cell boundaries. One of four OECP-treated animals ovulated prematurely. Normal Graafian follicles were present in the remaining ovaries. These results confirmed the findings of the earlier study (Choudary \& Greenwald, 1968a). Since OECP is an esterified oestrogen with a prolonged biological half-life, it was of interest to study the effect of an oestrogen with a short period of action. Accordingly, three cyclic animals were injected with $10 \mu \mathrm{g}$ of oestrone on Day 1 of the cycle. On Day 10, the corpora lutea of all animals appeared grossly chalky in colour though histological examination revealed luteal regression in only one animal (Table 1, Group 3).

Further experiments were carried out to determine whether OECP induced luteal regression in the cyclic guinea-pig by inhibiting the secretion of pituitary gonadotrophins. Groups of cyclic guinea-pigs were given a single injection of OEGP at Day 1 and individual gonadotrophins for 9 days; luteal status was determined on Day 10 (Table 1, Groups 4 to 8 ). Of all the treatments, only FSH at a dose of $200 \mu \mathrm{g}$ was able, to a limited extent, to counteract the luteo- 
lytic effect of the oestrogen (Table 1, Group 8 ). The corpora lutea showed early signs of regression in a reduced cytoplasmic: nuclear ratio and incipient vacuolization in the peripheral cells. Although the diameters of corpora lutea were significantly $(P<0.0125)$ greater than in animals receiving OECP alone, they were not comparable to the size of corpora lutea in control animals (Table 1, Groups 1, 2 and 8). The daily injection of $200 \mu \mathrm{g} \mathrm{FsH} \mathrm{also} \mathrm{stimulated}$ other ovarian components. This was reflected in a significantly $(P<0.05)$ heavier weight of the ovaries $(137.5 \mathrm{mg} \pm 1.4$ for the $200 \mu \mathrm{g}$ group, $98.0 \mathrm{mg} \pm$ 14.2 for the $50 \mu \mathrm{g}$ group), than in control animals.

Neither prolactin nor LH was able to arrest the luteal regression induced by OECP, as judged by gross and histological criteria (Table 1, Groups 2, 4, 5 and $6)$. The corpora lutea of animals treated with these hormones regressed completely. The ovaries of animals receiving both OECP and prolactin contained small, normal Graafian follicles and large, atretic follicles. The ratio of fibrous

TABLE 2

EFFECT OF GOMBINATIONS OF OESTRADIOL CYGLOPENTYLPROPIONATE AND GONADOTROPHINS ON THE CORPORA LUTEA OF CYCLIC GUINEA-PIGS

\begin{tabular}{|c|c|c|c|c|c|c|}
\hline \multirow{2}{*}{$\begin{array}{l}\text { Group } \\
\text { No. }\end{array}$} & \multicolumn{4}{|c|}{ Treatment $\ddagger$} & \multirow{2}{*}{$\begin{array}{l}\text { Mean diameter of } C L \\
\quad(m m \pm S . E .)\end{array}$} & \multirow{2}{*}{$\begin{array}{c}\text { Normal } C L / \mathcal{N} o . \\
\text { animals* }\end{array}$} \\
\hline & $\underset{(\mu g)}{O E C P}$ & $\begin{array}{l}F S H \\
(\mu g)\end{array}$ & $\begin{array}{c}L H \\
(\mu g)\end{array}$ & $\begin{array}{l}\text { Prolactin } \\
\quad(m g)\end{array}$ & & \\
\hline $\begin{array}{l}1 \\
2 \\
3 \\
4 \\
5\end{array}$ & $\begin{array}{l}10 \\
10 \\
10 \\
10 \\
10\end{array}$ & $\begin{array}{r}- \\
50 \\
100 \\
100\end{array}$ & $\begin{array}{l}\overline{10} \\
\frac{7}{10}\end{array}$ & $\begin{array}{l}-1 \\
1 \\
1 \\
-\end{array}$ & $\begin{array}{ll}0.74 \pm 0.09 & (15) \dagger \\
0.70 \pm 0.06 & (14) \\
0.83 \pm 0.05 & (10) \\
0.93 \pm 0.08 & (11) \\
0.89 \pm 0.04 & (7)\end{array}$ & $\begin{array}{l}0 / 4 \\
0 / 4 \\
0 / 4 \\
0 / 4 \\
0 / 3\end{array}$ \\
\hline
\end{tabular}

* No. of animals having normal cL on Day 10.

$\dagger$ Number in parentheses refers to number of cL measured.

$\mp$ OECP was administered on Day 1 ; individual gonadotrophins were administered daily on Days 1 to 9 .

connective-tissue elements to follicular structures was high. Two of four animals treated with OECP and $10 \mu \mathrm{g}$ of $\mathrm{LH}$ and one of four animals treated with OECP and $50 \mu \mathrm{g}$ of $\mathrm{LH}$ had new ovulations. The corpora lutea of animals injected with $50 \mu \mathrm{g}$ of $\mathrm{LH}$ were significantly $(P<0.025)$ smaller than those of animals treated with $10 \mu \mathrm{g}$ of $\mathrm{LH}$ (Table 1, Groups 5 and 6). Since LH by itself exerts a luteolytic effect on the corpora lutea of several species (Choudary \& Greenwald, 1968b), it was of interest to determine the effect of this hormone on the corpora lutea of cyclic guinea-pigs. Neither LH alone nor its injection combined with prolactin affected the corpora lutea (Table 1, Groups 1,9 and $10)$.

The above results suggested that OECP was inhibiting pituitary FSH secretion. The fact that exogenous FsH was only partially successful in protecting the corpora lutea against the damaging effects of OECP raised several questions: (1) Is OEGP inhibiting the secretion of more than one gonadotrophic hormone? If so, does the maintenance of the corpus luteum in the cyclic guinea-pig require a hormonal complex? (2) Is the rate of absorption and degradation of ovine FSH (injected in saline only once a day) too rapid to sustain normal 
corpora lutea? (3) Does the daily injection of a foreign protein such as ovine FSH for 9 days evoke an antibody response, thus lessening the effectiveness of the exogenous hormone? To answer the first question, groups of cyclic guineapigs were given OECP on Day 1 and various combinations of gonadotrophins on Days 1 to 9 (Table 2). None of the hormonal combinations counteracted the luteolytic effect of OECP (Table 2). The corpora lutea of animals treated with both prolactin and $\mathbf{L H}$ had degenerated. Their mean diameters were also significantly $(P<0.05)$ smaller than the corpora lutea of animals injected with prolactin and $100 \mu \mathrm{g}$ of FSH (Table 2, Groups 2 and 4). One of three animals receiving the former treatment had a new set of corpora lutea. The corpora lutea of animals given combinations that included FSH were histologically in an early stage of regression. None was equal in size to the corpora lutea of animals treated with $200 \mu \mathrm{g}$ of FSH in saline (Table 1, Group 8: Table 2, Groups 3 to 5 ).

To answer the second question, OEGP was combined with PMsG (Table 3, Groups 5 to 8 ) which is predominantly FsH-like in its actions on the ovary and remains in circulation for a prolonged period. Treatment with 10 or 25 i.u. of PMSG on Days 1 to 9 blocked the luteolytic action of OECP in the majority of animals. By histological criteria, corpora lutea of four of five animals treated with 10 i.u. PMSG were normal; the corpora lutea measured $1.08 \mathrm{~mm}$ in the remaining guinea-pig. The corpora lutea were normal in three of five animals treated with 25 i.u. PMSG and measured 1.11 and $1.12 \mathrm{~mm}$ in the regressing ovaries. There was no statistically significant difference between the size of maintained corpora lutea in PMSG-treated animals and those of control guineapigs (Table 3, Groups 1, 5 and 6). Treatment with 25 i.u. PMSG also caused excessive interstitial development which was reflected in the ovarian weights of the animals. The ovaries were significantly $(P<0.05)$ heavier $(222.9 \mathrm{mg} \pm$ $51.0)$ than the ovaries of animals treated with OECP alone (124.8 $\mathrm{mg} \pm 6.2)$.

The effect of postponing the onset of PMSG treatment was also determined (Table 3, Groups 7 and 8). The corpora lutea of animals killed on Day 10, which had received PMSG injections beginning on Day 2, were histologically normal in two of four animals (Table 3, Group 7). The corpora lutea measured 0.73 and $1.04 \mathrm{~mm}$ in the other two sets of ovaries. The corpora lutea of animals in which PMSG treatment was deferred until Day 4 were all regressing both by gross and histological criteria. They were significantly $(P<0.01)$ smaller than the corpora lutea of animals in which PMSG treatment was initiated on Day 1 (Table 3, Groups 5 and 8). The corpora lutea of animals treated with OECP on Day 1 could not be sustained by PMSG treatment beginning on Day 4, since they began to regress histologically on Day 3 (Choudary \& Greenwald, 1968a).

Earlier experiments involving PMSG treatment indicated that the failure of FSH injected in saline to block completely the adverse effect of OECP might be due to its rapid absorption and degradation. This assumption was tested by injecting OECP-treated animals with FSH reconstituted in a medium that delayed its rate of absorption and thereby prolonged its action. Cyclic animals treated with OECP on Day I were injected subcutaneously with $200 \mu \mathrm{g}$ of FSH in beeswax-sesame oil suspension on Days 1 through 9 (Table 3, Group 4). 
This treatment sustained corpora lutea in the majority of animals. Histological examination of the ovaries revealed extensive follicular development and interstitial oedema. The corpora lutea were normal in three animals and equal in size to those of control and PMSG-treated animals (Table 3, Groups 1, 4 and 5). In the remaining two animals, the corpora lutea were undergoing early regression and measured 0.66 and $1.0 \mathrm{~mm}$.

TABLE 3

EFFECT OF COMBINING OESTRADIOL GYCLOPENTYLPROPIONATE WITH PMSG OR FSH ON THE CORPORA LUTEA OF CYGLIC GUINEA-PIGS

\begin{tabular}{|c|c|c|c|c|}
\hline $\begin{array}{l}\text { Group } \\
\text { No. }\end{array}$ & Treatment & $\begin{array}{l}\text { Days of } \\
\text { treatment }\end{array}$ & $\begin{array}{l}\text { Mean diameter of } C L \\
(m m \pm S . E .)\end{array}$ & $\begin{array}{c}\text { Normal CL/No. } \\
\text { animals }\end{array}$ \\
\hline $\begin{array}{l}1 \\
2 \\
3\end{array}$ & $\begin{array}{l}\text { Control } \\
10 \mu \mathrm{g} \mathrm{OECP} \\
10 \mu \mathrm{g} \mathrm{OECP}+200 \mu \mathrm{g} \mathrm{FSH} \text { in saline }\end{array}$ & \multirow{6}{*}{$\begin{array}{l}1 \\
1 \\
1 \\
1 \text { to } 9 \\
1 \\
1 \text { to } 9 \\
1 \text { to } 9 \\
1 \text { to } 9 \\
1 \text { to } 9 \\
1 \text { to } 9 \\
4 \text { to } 9\end{array}$} & $\begin{array}{l}1.44 \pm 0.06 \quad(17) \dagger \\
0.74 \pm 0.09(15) \\
1.04 \pm 0.04 \quad(18)\end{array}$ & $\begin{array}{l}5 / 5 \\
0 / 4 \\
0 / 4\end{array}$ \\
\hline 4 & $10 \mu \mathrm{g} \mathrm{OECP}+200 \mu \mathrm{g}$ FSH in beeswax oil & & $1 \cdot 33 \pm 0.13 \quad(7) \ddagger$ & $3 / 5$ \\
\hline 5 & $10 \mu \mathrm{g} \mathrm{OECP}+10$ i.u. PMSG & & $1.42 \pm 0.05(11) \ddagger$ & $4 / 5$ \\
\hline 6 & $10 \mu \mathrm{g}$ OECP +25 i.u. PMSG & & $1 \cdot 33 \pm 0 \cdot 11 \quad(10) \ddagger$ & $3 / 5$ \\
\hline 7 & $10 \mu \mathrm{g} \mathrm{OECP}+10$ i.u. PMSG & & $1.24(1 \cdot 10$ & $2 / 4$ \\
\hline 8 & $10 \mu \mathrm{g}$ OECP +10 i.u. PMSG & & $1 \cdot 11 \pm 0.09$ & $0 / 4$ \\
\hline
\end{tabular}

* No. animals having normal cL on Day 10.

$\uparrow$ Number in parentheses refers to number of CL measured.

$\ddagger$ Mean calculated only on normal cL.

\section{DISCUSSION}

The results of the preliminary experiments and a recent report by Heap, Perry \& Rowlands (1967) indicate that the formation of deciduomata associated with uterine trauma is not a reliable end point for assessing luteal status in cyclic guinea-pigs. The size and morphology of the corpus luteum serve as better end points of luteal activity in this species.

The corpus luteum in the cyclic guinea-pig reaches its maximal size by Day 10 of the oestrous cycle and thereafter undergoes regression. Administration of oestrogen on Day 1 or 4 induces premature luteal regression, but neither a single injection on Day 6 (Choudary \& Greenwald, 1968a) nor daily treatment with a high dose from Day 6 onwards (Spies $e t$ al., 1964) adversely affects the corpus luteum. If the luteolytic effect of oestrogen is the result of a direct action on the corpus luteum, regression should occur after oestrogen treatment on any day up to Day 10 of the cycle. It follows that the mechanism by which oestrogen induces luteolysis involves an indirect effect, possibly by altering the secretion of gonadotrophins by the pituitary (Deanesly, 1963) or the secretion of FSH (Choudary \& Greenwald, 1968a).

The partial ability of FSH to counteract the luteolytic effect of oestrogen (Table 1, Group 8) suggested that oestrogen might be inducing luteal regression 
by inhibiting the secretion of another gonadotrophin in addition to FSH, but none of the combinations of FSH, LH or prolactin (Table 2, Groups 2 to 5) counteracted the luteolytic effect of oestrogen. Furthermore, the injection of $100 \mu \mathrm{g}$ of FSH with prolactin or LH (Table 2, Groups 3 to 5) was not as effective as $200 \mu \mathrm{g}$ of FSH alone in sustaining the corpora lutea (Table 1, Group 8). The LH contaminant in the ovine FSH does not appear to be responsible for the apparent luteotrophic effect produced by FsH since LH, alone (Table 1, Groups 5 and 6) or combined with prolactin (Table 1, Group 2), was unable to counteract the luteolytic effect of oestrogen. These results agree with the report of Deanesly (1966) that LH has neither a luteotrophic nor a luteolytic effect in the cyclic guinea-pig.

Since treatment with PMSG or FSH in beeswax-oil suspension (Table 3, Groups 4 to 6) successfully maintained the corpora lutea of OECP-treated animals, the limited efficacy of FSH in saline appears to be due to its rapid rate of release. When compared to that of the rat, the concentration of FsH in the pituitary of the guinea-pig is extremely low (D'Angelo, 1966), which is probably indicative of a rapid turnover of this hormone under physiological conditions.

Since exogenous FSH or an FSH-like hormone (PMSG) can reverse the luteolytic effect of oestrogen in the majority of animals, it appears likely that oestrogen induces luteal regression by inhibiting pituitary secretion of FSH. It is equally evident that FSH is involved in the development of the corpus luteum in the cyclic guinea-pig. This does not rule out the possibility that other gonadotrophic hormones may also be essential. In the pregnant hamster, exogenous oestrogen induces luteal regression by inhibiting the pituitary secretion of FSH which, together with prolactin, constitutes the minimal luteotrophic complex (Greenwald, 1967). Previous attempts to demonstrate the luteotrophic influence of prolactin in the intact cyclic guinea-pig failed (Aldred, Sammelwitz \& Nalbandov, 1961). However, the inability to extend the life-span of the corpus luteum in intact cyclic animals by prolonged administration of prolactin does not exclude the possibility of a luteotrophic role for prolactin.

\section{ACKNOWLEDGMENTS}

This is a contribution from The Research Professorship in Human Reproduction. J.B.R.C. was supported by a Ford Foundation post-doctoral fellowship. The research was supported by grants from the U.S.P.H.S., N.I.H. (HD 00596) and The Ford Foundation. We thank The Endocrinology Study Section, N.I.H. for providing the ovine gonadotrophins and Ayerst Laboratories for furnishing the PMSG.

\section{REFERENCES}

Aldred, J. P., Sammelwitz, P. H. \& Nalbandov, A. V. (1961) Mechanism of formation of corpora lutea in guinea-pigs. J. Reprod. Fert. 2, 394.

Choudary, J. B. \& Greenwald, G. S. (1968a) Luteolytic effect of oestrogen on the corpora lutea of the cyclic guinea-pig. F. Reprod. Fert. 16, 333.

Choudary, J. B. \& Greenwald, G. S. (1968b) Comparison of the luteolytic action of LH and estrogen in the hamster. Endocrinology, 83, 129. 
D'ANgelo, S. A. (1966) A comparative study of TSH and FSH secretion in rat and guinea pig: effects of gonadectomy and goitrogens. Endocrinology, 78, 1230.

DeanesLy, R. (1963) Further observations on the effects of oestradiol on tubal eggs and implantation in the guinea-pig. 7 . Reprod. Fert. $5,49$.

Deanesly, R. (1966) The effects of purified sheep luteinizing hormone on the guinea-pig ovary. $\mathcal{F}$. Reprod. Fert. I1, 303.

GREENWALD, G. S. (1965) Luteolytic effect of estrogen on the corpora lutea of pregnancy of the hamster. Endocrinology, 76, 1213.

GreENWALd, G. S. (1967) Luteotropic complex of the hamster. Endocrinology, 80, 118.

Heap, R. B., Perry, J. S. \& Rowlands, I. W. (1967) Corpus luteum function in the guinea-pig; arterial and luteal progesterone levels, and the effects of hysterectomy and hypophysectomy. 7. Reprod. Fert. 13, 537.

Snedecor, G. (1965) Statistical methods, 5th edn. Iowa State University Press, Ames, Iowa.

SpIes, H. G., GreR, H. T. \& WhEAT, J. F. (1964) Ovarian changes in hormone treated hysterectomized and cycling guinea pigs. Trans. Kans. Acad. Sci. 67, 517.

Wiltank, J. N. (1966) Modification of ovarian activity in the bovine following injection of oestrogen and gonadotrophin. F. Reprod. Fert., Suppl. 1, 1. 